\title{
Non-stop industries were the main source of air pollution during the 2020 coronavirus lockdown in the North China Plain
}

\author{
Zhen $\mathrm{Li}^{1}$ · Shaocai Yu${ }^{1}(1) \cdot$ Mengying $\mathrm{Li}^{1} \cdot$ Xue Chen ${ }^{1} \cdot$ Yibo Zhang ${ }^{1} \cdot$ Jiali $\mathrm{Li}^{1} \cdot$ Yapping Jiang ${ }^{1} \cdot$ Weiping $\mathrm{Liu}^{1}$. \\ Pengfei Li ${ }^{2}$ Eric Lichtfouse ${ }^{3,4}$ (i)
}

Received: 4 February 2021 / Accepted: 27 August 2021 / Published online: 30 October 2021

(c) The Author(s), under exclusive licence to Springer Nature Switzerland AG 2021

\begin{abstract}
Despite large decreases of emissions of air pollution during the coronavirus disease 2019 (COVID-19) lockdown in 2020, an unexpected regional severe haze has still occurred over the North China Plain. To clarify the origin of this pollution, we studied air concentrations of fine particulate matter $\left(\mathrm{PM}_{2.5}\right), \mathrm{NO}_{2}, \mathrm{O}_{3}, \mathrm{PM}_{10}, \mathrm{SO}_{2}$, and $\mathrm{CO}$ in Beijing, Hengshui and Baoding during the lockdown period from January 24 to 29, 2020. Variations of $\mathrm{PM}_{2.5}$ composition in inorganic ions, elemental carbon and organic matter were also investigated. The HYSPLIT model was used to calculate backward trajectories and concentration weighted trajectories. Results of the clustertrajectory analysis and model simulations show that the severe haze was caused mainly by the emissions of northeastern non-stopping industries located in Inner Mongolia, Liaoning, Hebei, and Tianjin. In Beijing, Hengshui and Baoding, the mixing layer heights were about $30 \%$ lower and the maximum relative humidity was $83 \%$ higher than the annual averages, and the average wind speeds were lower than $1.5 \mathrm{~m} \mathrm{~s}^{-1}$. The concentrations of $\mathrm{NO}_{3}{ }^{-}, \mathrm{SO}_{4}{ }^{2-}, \mathrm{NH}_{4}{ }^{+}$, organics and $\mathrm{K}^{+}$were the main components of $\mathrm{PM}_{2.5}$ in Beijing and Hengshui, while organics, $\mathrm{K}^{+}, \mathrm{NO}_{3}{ }^{-}, \mathrm{SO}_{4}{ }^{2-}$, and $\mathrm{NH}_{4}{ }^{+}$were the main components of $\mathrm{PM}_{2.5}$ in Baoding. Contrary to previous reports suggesting a southerly transport of air pollution, we found that northeast transport caused the haze formation.
\end{abstract}

Keywords Spring festival $\cdot$ COVID-19 $\cdot$ North China Plain $\cdot$ Haze

Shaocai Yu

shaocaiyu@zju.edu.cn

$\triangle$ Pengfei Li

lpf_zju@163.com

1 Key Laboratory of Environmental Remediation and Ecological Health, Ministry of Education; Research Center for Air Pollution and Health, College of Environmental and Resource Sciences, Zhejiang University, Hangzhou 310058, Zhejiang, People's Republic of China

2 College of Science and Technology, Hebei Agricultural University, Baoding 071000, Hebei, People's Republic of China

3 Aix-Marseille Univ, CNRS, IRD, INRAE, CEREGE, Europole Mediterraneen de L'Arbois, Avenue Louis Philibert, 13100 Aix en Provence, France

4 State Key Laboratory of Multiphase Flow in Power Engineering, Xi' an Jiaotong University, Xi' an 710049, Shaanxi, People's Republic of China

\section{Introduction}

Haze is a weather phenomenon in which dust, smog, and other dry particles affect the atmospheric visibility (Cai et al. 2017; Chang et al. 2009). The USA and European countries began to experience haze in the 1950s, but after decades of governance, air quality has been greatly improved. Unlike the haze in London in 1952 caused by coal burning and Los Angeles smog caused by vehicle emissions in the 1950s, haze in China is the consequence of diverse and high primary emissions, and efficient secondary generations (An et al. 2019). Although the Chinese government has made many years of efforts to control haze by transferring heavy industries from core cities to neighboring cities recently, the North China Plain has a high incidence of heavy haze in winter, and air pollutions there are more serious during the Spring Festival (Xiao et al. 2015; An et al. 2019). The Spring Festival is the most important and lively traditional festival in China, marking the beginning of the Lunar New Year by setting off fireworks and firecrackers. Previous studies have shown that residential heating, industrial production, 
and vehicle emissions caused severe haze pollution in North China Plain in winter (Li et al. 2014; Zhang et al. 2010; Kong et al. 2015).

Meanwhile, the topography and emission characteristics in the North China Plain (Zhang et al. 2019) are conducive to the regional transport and accumulation of pollutants because its north and west sides are Yanshan and Taihang Mountains, respectively. For example, in the winter of 2013, a nationwide haze broke out in China, especially in the North China Plain. Due to the fact that North China Plain is the largest industrial urban agglomeration in China, North China Plain bear the brunt of nationwide haze in 2013. The peak mass concentration of $\mathrm{PM}_{2.5}$ (aerodynamic equivalent diameter less than or equal to $2.5 \mu \mathrm{m}$ ) in Beijing in January 2013 reached $855 \mu \mathrm{g} \mathrm{m}^{-3}$ (Jin et al. 2020; Sun et al. 2017; Yang et al. 2015; Zheng et al. 2015). In addition to the impacts from local emissions, the average contribution rates of regional transport to Beijing's $\mathrm{PM}_{2.5}$ concentrations were found to exceed $40 \%$ during the whole year of 2013 (Ge et al. 2018). Several recent studies have shown that areas outside the North China Plain could bring pollutants into cities in the North China Plain through regional transports (Pu et al. 2020; Zhu et al. 2021).

Meteorological factors are another key factor causing air pollution in North China Plain (NCP) in winter. Stable weather conditions are not conducive to the diffusion and sedimentation of pollutants. When haze frequently occurs in winter, the North China Plain is mostly stable weather, which is generally characterized by low wind speed, low mixed layer height (MLH), and high relative humidity (Beyrich 1997; Jin et al. 2020; Sun et al. 2016; Yu et al. 2018; Kanawade et al. 2020; Zhu et al. 2018). The mixed layer is regarded as the link between the near surface and the free atmosphere and a low mixing layer height is not conducive to the diffusion of pollutants (Seidel et al. 2010).

Due to the outbreak of the COVID-19 pandemic, the Spring Festival in 2020 was very special with imposing extreme measures of nationwide lockdown by the Chinese government. The national emergency responses include extension of the Spring Festival holiday, suspension of all public transportation, closes of schools and entertainment venues, prohibition of public gatherings, enhancement of social distancing, and stay-at-home orders and closes of non-essential businesses (Wang et al. 2020a, b; Wang et al. 2021). Some recent scientific studies have shown that the improvement of air quality was one of the social benefits (Dutheil et al. 2020; He et al. 2020), while other studies have shown that limiting human activities by lockdown were not the fundamental way to alleviate air pollution (Wang et al. 2020a, b; Chang et al. 2020). It is worth studying why the unexpected haze problem still existed over the North China Plain when the air pollutant emissions were significantly reduced during the COVID-19 pandemic. The reduction of emissions from traffic and industrial sources during the COVID-19 lockdown in China provided a unique nature experiment for evaluating the efficiency of air pollution control measures (Le et al. 2020). The overall goal of this study is to investigate the regional severe haze over the North China Plain during the COVID-19 lockdown period from January 24 to January 29, 2020, by conducting a detailed analysis of the characteristics of haze at three representative cities in the North China Plain and digging the origins of the haze formation. The study explored the impact of regional transport on the formation of haze by identifying the pollution source areas of the target cities, and assessed the role of meteorological factors and ground emissions in the special atmospheric pollution during the lockdown.

\section{Experimental}

\section{Observational data}

The study period was from January 24 to January 29, 2020, of which January 24 is the New Year's Eve of 2020 and the first day when China adopted lockdown measures. Figure 1a shows the North China Plain area (Zhang et al. 2019), which spans 5 provinces (Hebei, Shandong, Henan, Anhui, and Jiangsu) and two municipality cities (Beijing, Tianjin), and is one of the three plains and the most populous plain in China. The three receptor cities selected in this study are Beijing, Hengshui and Baoding, all located in the northern part of the North China Plain. One of the reasons for this selection is that the observational data in the three cities were available. Figure S1 shows that the North China Plain (NCP) area borders Yanshan Mountain to the north, Taihang Mountain to the west, and Bohai Sea to the east. Hourly $\mathrm{PM}_{2.5}, \mathrm{NO}_{2}, \mathrm{O}_{3}, \mathrm{PM}_{10}, \mathrm{SO}_{2}$, and $\mathrm{CO}$ concentrations in three representative cities (there are 12, 4 and 6 monitoring stations in Beijing, Hengshui and Baoding cities, respectively) were obtained from China National Environmental Monitoring Center (CNEMC, http://www. cnemc.cn). The hourly chemical component concentrations of $\mathrm{PM}_{2.5}$ at three representative cities were obtained from the National Air Pollution Prevention and Control Joint Center (https://view.inews.qq.com/media/6474488). The chemical components include water-soluble inorganic ions (WSIIs) $\left(\mathrm{Cl}^{-}, \mathrm{NO}_{3}{ }^{-}, \mathrm{SO}_{4}{ }^{2-}, \mathrm{NH}_{4}{ }^{+}, \mathrm{Na}^{+}, \mathrm{K}^{+}, \mathrm{Mg}^{2+}\right.$ and $\left.\mathrm{Ca}^{2+}\right)$, elemental carbon (EC) and organic matter (OM). According to the hourly concentrations of $\mathrm{PM}_{2.5}$, the pollution levels were divided into light haze $\left(75 \leq \mathrm{PM}_{2.5}<115 \mu \mathrm{g} \mathrm{m}^{-3}\right)$, moderate haze $\left(115 \leq \mathrm{PM}_{2.5}<150 \mu \mathrm{g} \mathrm{m}^{-3}\right)$, heavy haze $\left(150 \leq \mathrm{PM}_{2.5}<250 \mu \mathrm{g} \mathrm{m}^{-3}\right)$, and severe haze $\left(\mathrm{PM}_{2.5} \geq 250 \mu \mathrm{g} \mathrm{m}^{-3}\right)$. The observed meteorological data were derived from the National Meteorological Data Center website (http://www.nmic.cn/site/index.html). 
(a)
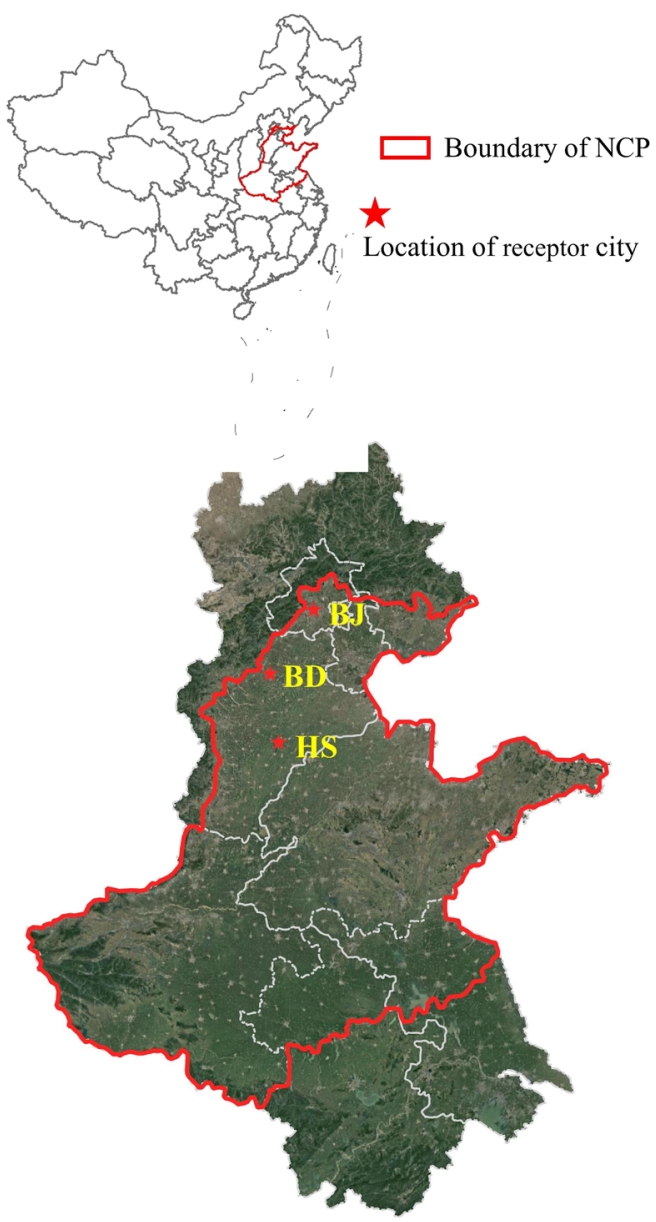

(b)

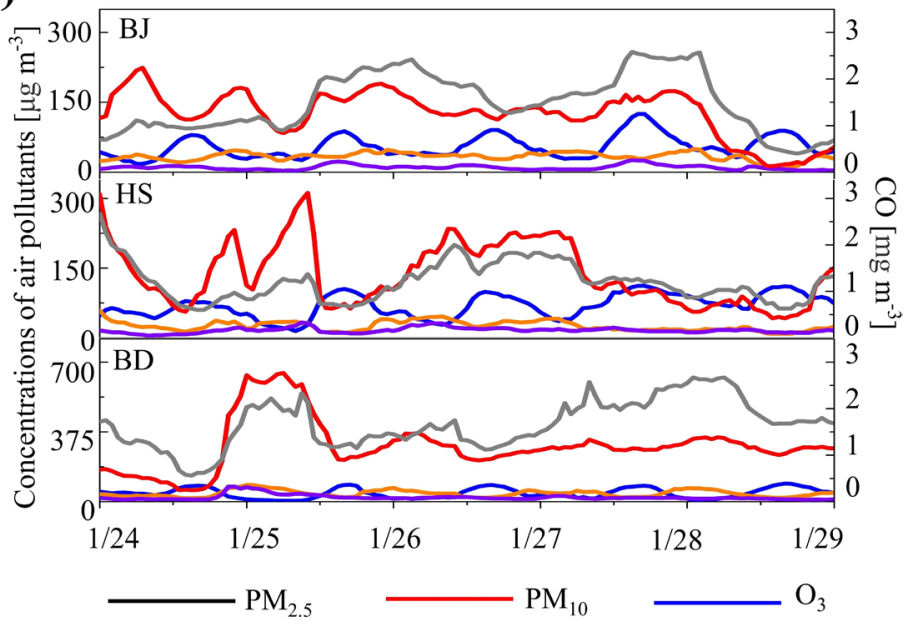

(c)

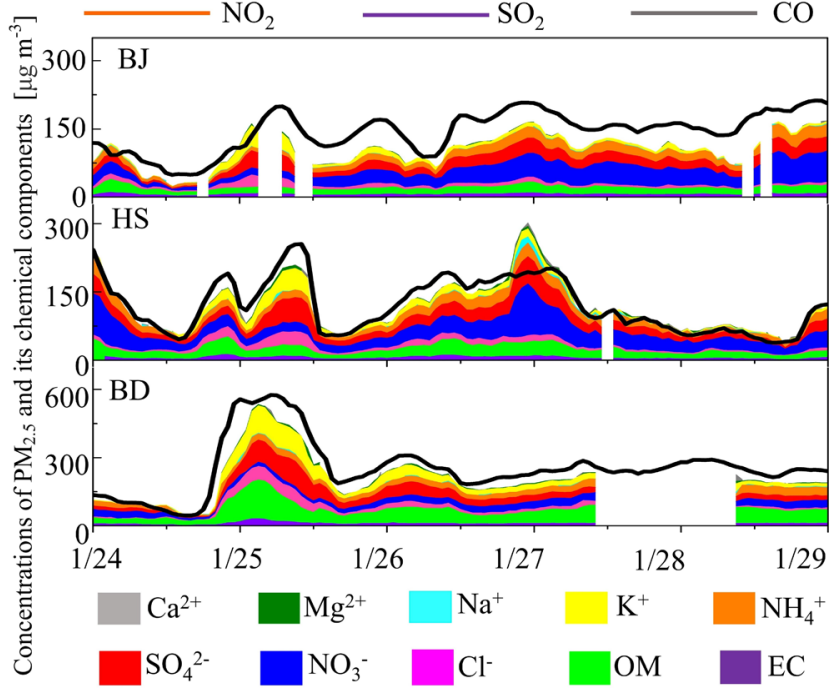

Fig. 1 a Map of China showing the boundary of North China Plain (NCP) and locations of Beijing (BJ), Hengshui (HS), and Baoding (BD) cities. b Hourly mass concentrations of five air pollutants; c Hourly mass concentrations of $\mathrm{PM}_{2.5}$ and chemical components in Beijing (BJ), Hengshui (HS), and Baoding (BD) cities during the study period (January 24 to January 29, 2020). The mass concentrations of chemical components were stacked in the figure. The highest values of $\mathrm{PM}_{10}, \mathrm{O}_{3}, \mathrm{NO}_{2}, \mathrm{SO}_{2}$ and $\mathrm{CO}$ were $692 \mu \mathrm{g} \mathrm{m}^{-3}$ in Baoding,

The meteorological data with a high spatial resolution of $0.5^{\circ} \times 0.5^{\circ}$ required for the Hybrid single-particle Lagrangian integral trajectory (HYSPLIT) model were obtained from the NOAA website (ftp://arlftp.arlhq.noaa.gov/pub/ archives/gdas0p5).

\section{The HYSPLIT model}

We used the HYSPLIT model to calculate backward trajectories and concentration weighted trajectories (CWT). The backward trajectory provides a transport path for air pollutants, which is used to determine whether the highconcentration pollutants in one location originate from the
$125 \mu \mathrm{g} \mathrm{m}^{-3}$ in Beijing, $90 \mu \mathrm{g} \mathrm{m}^{-3}$ in Baoding, $81 \mu \mathrm{g} \mathrm{m}^{-3}$ in Baoding, and $2.7 \mu \mathrm{g} \mathrm{m}^{-3}$ in Baoding, respectively. The maximum $\mathrm{PM}_{2.5}$ concentrations in Beijing, Hengshui and Baoding were $266 \mu \mathrm{g} \mathrm{m}^{-3}$ (13:00, January 28), $286 \mu \mathrm{g} \mathrm{m}^{-3}$ (11:00, January 26), and $641 \mu \mathrm{g} \mathrm{m}^{-3}$ (3:00, January 25), respectively. The concentrations of $\mathrm{NO}_{3}{ }^{-}, \mathrm{SO}_{4}{ }^{2-}$, $\mathrm{NH}_{4}^{+}$, organics and $\mathrm{K}^{+}$were the main components of fine particles $\left(\mathrm{PM}_{2.5}\right)$ in Beijing and Hengshui, while organics, $\mathrm{K}^{+}, \mathrm{NO}_{3}{ }^{-}, \mathrm{SO}_{4}{ }^{2-}$, and $\mathrm{NH}_{4}{ }^{+}$were the main components of $\mathrm{PM}_{2.5}$ in Baoding

pollution transport of another location (Draxler and Hess 1998). This study calculated the $48 \mathrm{~h}$ backward trajectory of $\mathrm{PM}_{2.5}$ at a height of $100 \mathrm{~m}$ with the starting calculation time points for each day during the study period on 00:00, 03:00, 06:00, 09:00, 12:00, 15:00, 18:00 and 21:00 (UTC time). One back trajectory for one monitoring station were calculated each time. Trajectory cluster analysis based on the trajectory space similarity is used to group a large number of trajectories. In this work, we used the angular distance to do cluster analysis which is based on the trajectory space similarity to group a large number of trajectories. This is mainly because the trajectories can be applied to locate the directions and sources from which the air masses reaching 
the receptor site had transported (Yan et al. 2015). The CWT method assigns a weighted concentration to each grid cell, which is obtained by averaging the sample concentrations associated with the trajectory passing through the grid cell (Reizer and Orza 2018). This method calculates the $C W T_{i j}$ value in each grid cell $(i, j)$ as follows (Hsu et al. 2003; Yan et al. 2015):

$C W T_{i j}=\frac{1}{\sum_{l=1}^{M} \tau_{i j l}} \sum_{l=1}^{M} C_{l} \tau_{i j l}$

where $l$ and $M$ represent the index and the total number of trajectories in the grid cell, respectively. $C_{l}$ is the concentration detected at the receptor position on the arrival of trajectory $l . \tau_{i j l}$ is the time that the trajectory $l$ spent in the grid cell $(i, j)$. A high $C W T_{i j}$ value indicates that the air mass with attributions of high potential pollution has a significant contribution to the receptor site (Yan et al. 2015). In order to find the specific location of the pollution sources, the common pollution source area calculation method of Chen et al (2020) was adopted to determine the common source area of $\mathrm{PM}_{2.5}$ in the three cities during the study period.

\section{Calculation of meteorological parameters}

This study used mixed layer height (MLH), $10 \mathrm{~m}$ wind speed (WS), relative humidity (RH) and static weather index to represent the meteorological conditions in the three recipient cities. The MLH values can be calculated using an empirical method as follows (Nozaki 1973; Beyrich 1997):

$M L H=\frac{121}{6}(6-P)\left(T-T_{d}\right)+\frac{0.169 P\left(U_{z}+0.257\right)}{12 \operatorname{fn}\left(Z / z_{0}\right)}$

$f=2 \Omega \sin \varphi$

where $P$ is Pasquill's stability coefficient, $T$ is the surface temperature, $T_{d}$ is the dew point temperature, $U_{z}$ is the average wind speed $(\mathrm{m} / \mathrm{s})$ at the height of $Z(Z=10 \mathrm{~m}), f$ is the Coriolis parameter $\left(\mathrm{s}^{-1}\right), z_{0}$ is the surface roughness (0.03-0.2 $\mathrm{m}$ for rural area, $0.8-2 \mathrm{~m}$ for urban area, and $1.4 \mathrm{~m}$ is used in this study), $\Omega$ is the Earth's angular velocity $\left(7.29 \times 10^{-5} \mathrm{rad} \mathrm{s}^{-1}\right)$, and $\varphi$ is the latitude value. Pasquill divides atmospheric stability into six levels from $\mathrm{A}$ to $\mathrm{F}$ (Pasquill 1961), and the six levels from A to F are replaced by $1-6$ numbers in this study.

By correlating the air pollutant levels with a combination of meteorological factors in a specific region or city, Zhang et al (2017) developed the stable weather index (SWI) which included the advection, vertical diffusion and humidity and other meteorological factors (Gong et al. 2021; Liu et al. 2021). A higher SWI value means a weaker diffusion of air pollutants. The detailed information about the calculation method of SWI can be found in Zhang et al (2017). In this study, the SWT values were calculated and used to assess the atmospheric stable states of the meteorological conditions.

\section{Modelling meteorological and chemical parmeters}

The offline weather research and forecasting (WRFv3.9.1)Community Multiscale Air Quality Modeling (CMAQv5.3.2) model was used to simulate spatiotemporal variations in meteorological and chemical parameters. Model configurations are listed in Table S1. In this study, the Carbon Bond 6 (CB6r3) scheme and AERO7 module were responsible for gas and aerosol chemistry simulations, respectively. The CMAQ version 5.3.2 (released in 2020) is the latest version and its major science advances in detail can be found in Murphy et al. (2021), Appel et al. (2021) and US EPA (2020). A brief summary relevant to the present study is presented here. Major science advances in the new aerosol module (AERO7) includes significant updates to secondary organic aerosol (SOA) chemistry, updates for chlorine, bromine, iodine chemistry, and halogen chemistries, and the addition of dimethyl sulfide (DMS) chemistry in the CB6r3 chemical mechanism (Appel et al. 2021). The CB6r3 is the most recent version of CB implemented in CMAQ53 with 4 heterogeneous reactions, 38 gas-phase reactions, and 44 gas-phase reactions and 10 heterogeneous reactions for iodine species, and 5 aqueous-phase reactions for bromine species (Appel et al. 2021).

The model domain covering China and a portion of East Asia with a horizontal resolution of $12 \mathrm{~km} \times 12 \mathrm{~km}$ and $345 \times 395$ grid cells is shown in Fig. S5. The WRFv3.9.1 (Skamarock et al. 2008) model was used to provide meteorological fields for chemical simulations. The configurations and components for the WRF-CMAQ model used in this study are the same as those in Yu et al. (2014) and are summarized in Table S1. The anthropogenic emissions for China were generated by the Emission Inventory of Air Benefit and Cost and Attainment Assessment System (EI-ABaCAS) developed by Tsinghua University (Zheng et al. 2018). The EI-ABaCAS includes 16 anthropogenic sectors: fertilizer application, livestock, domestic bio-fuel, combustion, fossil fuel, solvent and other use, industry combustion, open burning, power plant, cement steel, other industry process, industry solvent use, road and non-road transport. The natural sources for biogenic emissions were calculated inline using the Biogenic Emission Inventory System version 3.14 (BEISv3.14). 


\section{Results and discussion}

\section{Air pollutants and meteorological conditions during the severe haze period}

Figure 1 shows the time series of the concentrations of $\mathrm{PM}_{10}, \mathrm{O}_{3}, \mathrm{NO}_{2}, \mathrm{SO}_{2}, \mathrm{CO}, \mathrm{PM}_{2.5}$ and chemical components of $\mathrm{PM}_{2.5}$ in the three cities during the study period. The results show that the changing trends of air pollutants in the three cities were obviously different, indicating different $\mathrm{PM}_{2.5}$ formation mechanisms. The highest levels were $692 \mu \mathrm{g} \mathrm{m}^{-3}$ for $\mathrm{PM}_{10}$ in Baoding, $125 \mu \mathrm{g} \mathrm{m}^{-3}$ for $\mathrm{O}_{3}$ in Beijing, $90 \mu \mathrm{g} \mathrm{m}^{-3}$ for $\mathrm{NO}_{2}$ in Baoding, $81 \mu \mathrm{g} \mathrm{m}^{-3}$ for $\mathrm{SO}_{2}$ in Baoding, and $2.7 \mathrm{mg} \mathrm{m}^{-3}$ for $\mathrm{CO}$ in Baoding. The maximum $\mathrm{PM}_{2.5}$ concentrations in Beijing, Hengshui and Baoding were $266 \mu \mathrm{g} \mathrm{m}^{-3}$ at 13:00 January 28 in Beijing, $286 \mu \mathrm{g} \mathrm{m}^{-3}$ at 11:00, January 26 in Hengshui, and $641 \mathrm{\mu g} \mathrm{m}^{-3}$ at 3:00, January 25 in Baoding. Baoding experienced a one-day severe pollution process from January 24 to 25 , during which $\mathrm{PM}_{10}, \mathrm{NO}_{2}$ and $\mathrm{SO}_{2}$ all reached their peak values. The $\mathrm{K}^{+}, \mathrm{Mg}^{2+}, \mathrm{Cl}^{-}$and $\mathrm{Ca}^{2+}$ ions from fireworks as indicated in Fig. 1 increased sharply after January 24, and reached their peaks on January 25, being consistent with the fact that the air pollution emissions from fireworks and firecrackers flooded into the air on the New Year's Eve. This indicates that the fireworks and firecrackers still affected the formation of haze in the North China Plain during the lockdown period. In addition to being derived from fireworks and firecrackers, $\mathrm{K}^{+}$was also a tracer of biomass combustion (Cheng et al. 2013). The increases of $\mathrm{K}^{+}$also show that the suburban biomass burning contributed significantly to the $\mathrm{K}^{+}$in the three cities.

In Beijing, after experiencing two peaks and valleys from January 25 to January $26, \mathrm{PM}_{2.5}$ rebounded after 12 noon on January 26 and then remained at high concentrations above $147 \mu \mathrm{g} \mathrm{m}^{-3}$. This shows that after January 26, when local emissions were almost unchanged, regional transport made a certain contribution to Beijing's PM $_{25}$. The main component of $\mathrm{PM}_{2.5}$ in Beijing was water soluble inorganic ions (WSIIs) with an average proportion of $53.6 \%$ for $\mathrm{PM}_{2.5}$. The average concentration of $\mathrm{NO}_{3}{ }^{-}$in Beijing was $32.0 \mathrm{\mu} \mathrm{m}^{-3}$, accounting for $12.1-29.7 \%$ of $\mathrm{PM}_{2.5}$ with an average proportion of $20.9 \%$, while $\mathrm{SO}_{4}{ }^{2-}$ in Beijing ranged from $10 \mu \mathrm{g} \mathrm{m}^{-3}$ to $27.8 \mu \mathrm{g} \mathrm{m}^{-3}$, accounting for $12.2 \%$ of $\mathrm{PM}_{2.5}$ on average. The average relative humidity in Beijing was $60.7 \pm 16.4 \%$ (Fig. S2) during the study period, which promoted the formation of a large amount of $\mathrm{SO}_{4}{ }^{2-}$ from the heterogeneous chemical reactions and liquid phase oxidations of $\mathrm{SO}_{2}$. The concentrations of $\mathrm{NH}_{4}^{+}$ in in Beijing ranged from 8.9 to $21.9 \mu \mathrm{g} \mathrm{m}^{-3}$, with an average proportion of $10.4 \%$ for $\mathrm{PM}_{2.5}$. Since emissions from motor vehicles and industries have declined to a certain extent under the COVID-19 lockdown (Le et al. 2020), residential heating and non-stop industrial productions in Beijing emitted a certain amount of $\mathrm{NO}_{3}{ }^{-}, \mathrm{SO}_{4}{ }^{2-}$ and $\mathrm{NH}_{4}{ }^{+}$precursors.

In Hengshui, there were four peak values of $\mathrm{PM}_{2.5}$ concentrations in the early stage with decreasing trends in the later stage. The average percentage of WSIIs in $\mathrm{PM}_{2.5}$ in Hengshui was $71.6 \%$. Similar to Beijing, the main components of $\mathrm{PM}_{2.5}$ in Hengshui were $\mathrm{NO}_{3}{ }^{-}, \mathrm{SO}_{4}{ }^{2-}$ and $\mathrm{NH}_{4}{ }^{+}$, with average mass concentrations of $36.1 \pm 20.4 \mu \mathrm{g} \mathrm{m}^{-3}$, $22.3 \pm 13 \mu \mathrm{g} \mathrm{m}^{-3}$, and $16.9 \pm 7.6 \mu \mathrm{g} \mathrm{m}^{-3}$, respectively. The proportion of WSIIs in $\mathrm{PM}_{2.5}$ changed over time. For example, on January 25, the main component of $\mathrm{PM}_{2.5}$ was $\mathrm{SO}_{4}{ }^{2-}$ and on January 26 , the main component of $\mathrm{PM}_{2.5}$ turned to be $\mathrm{NO}_{3}{ }^{-}$, which peaked at night on January 26. Considering that the local emissions were relatively unchanged, this indicates that the contributions of regional transports to $\mathrm{PM}_{2.5}$ in Hengshui were considerable, and the formation mechanism of $\mathrm{PM}_{2.5}$ in Hengshui has changed. Figure $\mathrm{S} 2$ shows that the changes of relative humidity in Hengshui on January 25 were consistent with those of $\mathrm{PM}_{2.5}$. It should be noted that there were diurnal differences in the concentrations of $\mathrm{NO}_{3}{ }^{-}$in Hengshui with the average concentrations of $27.2 \mu \mathrm{g} \mathrm{m}^{-3}$ (daytime) and $40.7 \mu \mathrm{g} \mathrm{m}^{-3}$ (night). The higher night $\mathrm{NO}_{3}{ }^{-}$concentrations in Hengshui might be affected by external sources and stable weather conditions.

In Baoding, unlike Beijing and Hengshui, organic matter dominated $\mathrm{PM}_{2.5}$, accounting for $25 \pm 6.4 \%$ on average. The average concentrations of chemical components of $\mathrm{PM}_{2.5}$ in Baoding in the descending order were $60.3 \pm 19 \mu \mathrm{g} \mathrm{m}^{-3}$ for organic matter $(\mathrm{OM}), 35.2 \pm 20.1 \mathrm{\mu g} \mathrm{m}^{-3}$ for $\mathrm{K}^{+}$, $33.9 \pm 20.4 \mu \mathrm{g} \mathrm{m}^{-3}$ for $\mathrm{SO}_{4}{ }^{2-}, 26.6 \pm 7.0 \mu \mathrm{g} \mathrm{m}^{-3}$ for $\mathrm{NO}_{3}^{-}, 25.5 \pm 6.8 \mu \mathrm{g} \mathrm{m}^{-3}$ for $\mathrm{NH}_{4}^{+}, 16.6 \pm 11.7 \mu \mathrm{g} \mathrm{m}^{-3}$ for $\mathrm{Cl}^{-}, 10.7 \pm 3.3 \mu \mathrm{g} \mathrm{m}^{-3}$ for elemental carbon (EC), $8.3 \pm 3.4 \mu \mathrm{g} \mathrm{m}^{-3}$ for $\mathrm{Ca}^{2+}, 3.9 \pm 1.4 \mu \mathrm{g} \mathrm{m}^{-3}$ for $\mathrm{Mg}^{2+}$, and $2.9 \pm 0.5 \mu \mathrm{g} \mathrm{m}^{-3}$ for $\mathrm{Na}^{+} . \mathrm{PM}_{2.5}$ in Baoding peaked on January 25 with sharp drops in the next $24 \mathrm{~h}$ by $380 \mu \mathrm{g} \mathrm{m}^{-3}$ because of the diffusion caused by the increases of the mixed layer height (MLH, Fig. S2). The concentration of organic matter $(\mathrm{OM})$ in Baoding was extremely high, indicating that organic gas precursors played a key role in the formation of $\mathrm{PM}_{25}$ in Baoding. Note that the OM concentrations were still high after Jan 25 in Baoding because of the effects of the regional transports. The very high concentrations of $\mathrm{K}^{+}$ and $\mathrm{Cl}^{-}$in Boading's $\mathrm{PM}_{2.5}$ indicate substantial contributions from the emissions of fireworks and firecrackers. This is consistent with the findings of Tang et al (2016), who found that the $\mathrm{K}^{+}, \mathrm{Cl}^{-}, \mathrm{SO}_{4}{ }^{2-}, \mathrm{NH}_{4}{ }^{+}$, and $\mathrm{NO}_{3}{ }^{-}$concentrations in Tianjin's $\mathrm{PM}_{2.5}$ during the firework were $65.8,42.9$, $38.9,8.7$, and $1.9 \mu \mathrm{g} \mathrm{m}^{-3}$, respectively, and that the $\mathrm{K}^{+}$and $\mathrm{Cl}^{-}$concentrations during the peak period were 23.5 and 15.5 times higher than those during Chinese Lunar New 
Year, respectively. Since fireworks contained charcoal and organic materials used as adhesives, they were responsible for elevated $\mathrm{OC}$ and EC concentrations during the firework and firecracker events (Tsai et al. 2012; Kong et al. 2015). Since potassium compounds, e.g., $\mathrm{KNO}_{3}, \mathrm{KClO}_{3}, \mathrm{KClO}_{4}$, $\mathrm{K}_{2} \mathrm{CrO}_{4}$, and $\mathrm{K}_{2} \mathrm{Cr}_{2} \mathrm{O}_{7}$, in black powder are used as the main oxidizers, the corresponding chemical reactions, e.g., $2 \mathrm{KClO}_{3}=2 \mathrm{KCl}+3 \mathrm{O}_{2}$ and $\mathrm{KClO}_{4}=\mathrm{KCl}+2 \mathrm{O}_{2}$, can lead to high concentrations of $\mathrm{K}^{+}$and $\mathrm{Cl}^{-}$during the firework and firecracker events (Azhagurajan et al. 2011; Tang et al. 2016).

Figure $\mathrm{S} 2$ shows the time series of hourly meteorological elements in the three cities. The meteorological conditions in the three cities during the study period can be summarized as low MLH and wind speed (WS) but high stable weather index (SWI) and relative humidity. For example, the MLH mean values in Beijing, Hengshui, and Baoding were $448.2 \pm 294.1,497.3 \pm 209.1$, and $330.0 \pm 232.2 \mathrm{~m}$, respectively. Comparing to the annual average MLH values in Beijing and Shijiazhuang being $594 \pm 183 \mathrm{~m}$ and $464 \pm 183 \mathrm{~m}$, respectively (Zhu et al. 2018), the MLH values in the three cities during the study period can be considered as relatively low. The average WS in Beijing, Hengshui, and Baoding were $1.4 \pm 0.8,0.8 \pm 0.5$, and $0.8 \pm 0.8 \mathrm{~m} \mathrm{~s}^{-1}$, respectively. The low wind speeds in these three cities limit the diffusion of local sources. On the other hand, the maximum relative humidity in Beijing, Hengshui and Baoding were 83\%, 92\% and $97 \%$, respectively. The SWI ranges in Beijing, Hengshui and Baoding were 8-19,11-20 and 9-21, respectively. The high SWIs in the three cities indicate that the meteorological conditions were stable during the study period. In conclusion, the stable meteorological conditions in the three cities exacerbated the formation of the haze.

\section{Regional transport impacts based on the HYSPLIT analysis}

Table 1 summarizes the average concentrations of $\mathrm{PM}_{2.5}$ and its chemical components, and the percentages for each cluster and three cluster trajectories for each receptor city are shown in Fig. S3. The results of all backward trajectories in Fig. S3 indicate that most of the air masses came from Inner Mongolia, Liaoning, Hebei and Tianjin.

For Beijing, Cluster 1, which accounted for $54.1 \%$ and carried $51.0 \%$ of the pollution trajectories, transported from the neighboring areas to Beijing through a small area in northern Hebei province. Cluster 1 had the highest concentration of $\mathrm{PM}_{2.5}\left(177.3 \pm 61.2 \mu \mathrm{g} \mathrm{m}^{-3}\right)$, which was the most important transport path for $\mathrm{PM}_{2.5}$ in Beijing. Cluster 2 (3) accounted for $37.7 \%(8.2 \%)$ and carried $39.5 \%(9.5 \%)$ of the pollution trajectories. According to the concentrations of chemical components, Cluster 2 carries the most $\mathrm{K}^{+}$and
$\mathrm{Cl}^{-}$probably generated by firework because Cluster 2 was not a cross-sea transport as shown in Fig. S3.

For Hengshui, all cluster trajectories were cross-sea transports in the northeast direction with obvious long-distance transport characteristics as indicated in Fig. S3. Cluster 1 with the longest transport path came from western Inner Mongolia and Liaoning Province, accounting for $43.8 \%$ and carrying $44.3 \%$ of the pollution trajectories (see Table 1). Clusters 2 and 3 passed through western Liaoning, southern Tianjin, and northern Shandong. The $\mathrm{PM}_{2.5}$ concentrations $\left(157.6 \mu \mathrm{g} \mathrm{m}^{-3}\right)$ carried by the air mass in Cluster 2 was the highest. The $\mathrm{Na}^{+}$concentrations in Cluster 2 were the highest, further indicating that cross-sea transports had a certain influence on the formation of $\mathrm{PM}_{2.5}$ in Hengshui.

For Baoding, except for Cluster 3, the other two Clusters all passed through the western Liaoning and Inner Mongolia. Cluster 3, which accounted for $21.1 \%$ and carried $\mathrm{PM}_{2.5}$ with an average concentration of $216.7 \mu \mathrm{g} \mathrm{m}^{-3}$, moved around Baoding, indicating a great impact of local pollution sources on $\mathrm{PM}_{2.5}$ in Baoding. The percentages of Clusters 1 and 2 were $45.4 \%$ and $33.5 \%$, respectively, and Cluster 2 carried the highest concentration of $\mathrm{PM}_{2.5}\left(295.9 \mu \mathrm{g} \mathrm{m}^{-3}\right)$.

To further study the impact of regional transports on the formation of haze, Fig. 2 shows the 48-h backward trajectories in three cities, superimposed by the observed $\mathrm{PM}_{2.5}$ concentrations over the North China Plain every $12 \mathrm{~h}$ within $48 \mathrm{~h}$. As can be seen, the spatial variations of $\mathrm{PM}_{2.5}$ in the three cities were consistent with those of the monitoring stations on the transport paths. The pollution incidents in Beijing were a typical full-time severe pollution event. $\mathrm{PM}_{2.5}$ concentrations in Beijing were higher at 13:00 on January 28 than those in other four time points. From January 26 to January 28, there was a rising process of $\mathrm{PM}_{2.5}$ in the western cities of Liaoning, which were on the pollution transport path. The concentrations of $\mathrm{PM}_{2.5}$ in Beijing remained at a high level above $147 \mu \mathrm{g} \mathrm{m}^{-3}$, indicating that $\mathrm{PM}_{2.5}$ in western Liaoning was imported into Beijing along the pollution transport path. Figure 2 indicates that nearby cities located in the pollution transport path had a greater impact on the increases of Beijing's $\mathrm{PM}_{2.5}$. Figure 2 also shows that the spatial variations of $\mathrm{PM}_{2.5}$ concentrations in Hengshui and Baoding were consistent with those at the monitoring stations on the transport path. For the pollution event from January 24 to January 26, the cities in Liaoning province located on the northeast transport path for Hengshui experienced a substantial increase of $\mathrm{PM}_{2.5}$ within $24 \mathrm{~h}$ from 11:00 on January 24 to 11:00 on January 25 . The $\mathrm{PM}_{2.5}$ concentrations in Hengshui began to rise from 23:00 on January 25, and reached a peak on January 26. Baoding's $\mathrm{PM}_{2.5}$ experienced a sharp rise from 15:00 on January 24. At the same time, the concentrations of $\mathrm{PM}_{2.5}$ in cities of western Liaoning and Hebei Provinces on the transport path for Baoding also experienced the same rising processes. 
Table 1 Number of backward trajectories and average concentrations of $\mathrm{PM}_{2.5}$ and chemical components for different clusters in Beijing, Hengshui, and Baoding during the study period

\begin{tabular}{|c|c|c|c|c|c|c|c|c|c|}
\hline & \multicolumn{3}{|l|}{ Beijing } & \multicolumn{3}{|l|}{ Hengshui } & \multicolumn{3}{|l|}{ Baoding } \\
\hline & Cluster 1 & Cluster 2 & Cluster 3 & Cluster 1 & Cluster 2 & Cluster 3 & Cluster 1 & Cluster 2 & Cluster 3 \\
\hline $\begin{array}{l}\text { Number of } \\
\text { trajectories } \\
\text { (percent) }\end{array}$ & $309(54.1)$ & $215(37.7)$ & $47(8.2)$ & $84(43.8)$ & $72(37.5)$ & $36(18.8)$ & $129(45.4)$ & $95(33.5)$ & $60(21.1)$ \\
\hline $\begin{array}{l}\mathrm{PM}_{2.5}\left[\mu \mathrm{g} \mathrm{m}^{-3}\right] \\
\text { for all trajec- } \\
\text { tories }\end{array}$ & $177.3 \pm 61.2$ & $133.9 \pm 64.0$ & $136.2 \pm 50.7$ & $115.6 \pm 56.1$ & $140.0 \pm 49.9$ & $92.5 \pm 56.4$ & $168.0 \pm 94.1$ & $275.9 \pm 142.8$ & $206.1 \pm 57.5$ \\
\hline $\begin{array}{l}\text { Number of } \\
\text { polluted } \\
\text { trajectories* }\end{array}$ & $214(51)$ & $166(39.5)$ & $40(9.5)$ & $62(44.3)$ & $60(42.9)$ & $18(12.9 \%)$ & $104(42.1 \%)$ & $87(35.2 \%)$ & $56(22.7 \%)$ \\
\hline $\begin{array}{c}\mathrm{PM}_{2.5}\left[\mu \mathrm{g} \mathrm{m}^{-3}\right] \\
\text { for polluted } \\
\text { trajectories }\end{array}$ & $150.4 \pm 41.1$ & $157.3 \pm 53.3$ & $150.7 \pm 39.6$ & $138.1 \pm 47.5$ & $157.6 \pm 33.0$ & $132.2 \pm 56.0$ & $196.3 \pm 82.6$ & $295.9 \pm 132.2$ & $216.7 \pm 42.7$ \\
\hline$* * \mathrm{Ca}^{2+}$ & $1.4(0.1)$ & $0.8(0.04)$ & $0.8(0.04)$ & $2.6(0.9)$ & $2.8(0.7)$ & $2.5(1.3)$ & $12.5(0.3)$ & $10.3(0.3)$ & $12.5(0.3)$ \\
\hline $\mathrm{Mg}^{2+}$ & $1.3(0.3)$ & $1.3(0.3)$ & $1.2(0.3)$ & $1.8(0.8)$ & $2.4(0.5)$ & $1.8(0.7)$ & $3.2(1.0)$ & $3.4(0.9)$ & $3.2(1.3)$ \\
\hline $\mathrm{K}^{+}$ & $9.5(4.4)$ & $9.7(5.8)$ & $9.4(5.4)$ & $9.3(4.7)$ & $12.6(4.7)$ & $7.0(3.3)$ & $22.5(7.6)$ & $28.0(7.0)$ & $19.8(6.4)$ \\
\hline $\mathrm{Na}^{+}$ & $1.2(0.4)$ & $1.0(0.5)$ & $1.1(0.4)$ & $2.3(0.5)$ & $3.3(0.5)$ & $2.1(0.4)$ & $2.8(0.5)$ & $2.8(0.4)$ & $2.8(0.6)$ \\
\hline $\mathrm{NH}_{4}^{+}$ & $18.3(10.1)$ & $14.7(9.9)$ & $15.0(10.2)$ & $15.0(13.8)$ & $19.6(12.0)$ & $12.6(15.2)$ & $27.3(13.7)$ & $27.0(8.6)$ & $28.8(12.7)$ \\
\hline $\mathrm{SO}_{4}^{2-}$ & $22.9(12.6)$ & $18.7(12.5)$ & $18.6(12.6)$ & $18.0(15.9)$ & $25.0(14.7)$ & $14.7(16.9)$ & $23.7(11.7)$ & $31.2(9.7)$ & $25.8(11.5)$ \\
\hline $\mathrm{NO}_{3}^{-}$ & $40.0(22.0)$ & $30.4(20.2)$ & $31.3(21.1)$ & 30.7 (28.6) & $39.9(23.7)$ & $26.7(32.5)$ & $30.1(15.6)$ & $28.7(9.3)$ & 30.7 (13.5) \\
\hline $\mathrm{Cl}^{-}$ & $6.6(3.7)$ & $7.1(5.1)$ & $6.7(4.8)$ & $6.9(5.9)$ & $9.5(5.9)$ & $5.1(5.7)$ & $9.0(4.2)$ & $13.6(4.2)$ & $10.2(4.4)$ \\
\hline $\mathrm{OM}$ & $15.5(8.7)$ & $14.8(10.6)$ & $14.7(10.4)$ & $17.5(16.0)$ & $22.2(13.7)$ & $14.4(17.4)$ & $51.0(24.4)$ & $57.9(18.2)$ & $56.7(24.8)$ \\
\hline $\mathrm{EC}$ & $6.5(4.0)$ & $6.3(4.5)$ & $6.2(4.4)$ & $5.0(4.5)$ & $6.7(4.7)$ & $3.8(4.4)$ & $9.6(4.7)$ & $10.1(4.2)$ & $10.1(4.3)$ \\
\hline
\end{tabular}

For Beijing, Cluster 1 had the highest concentration of $\mathrm{PM}_{2.5}\left(177.3 \pm 61.2 \mu \mathrm{g} \mathrm{m}^{-3}\right)$, which was the most important transport path for $\mathrm{PM}_{2.5}$ in Beijing

According to the concentrations of chemical components, Cluster 2 carries the most $\mathrm{K}^{+}$and $\mathrm{Cl}^{-}$probably generated by firework because Cluster 2 was not a cross-sea transport as shown in Fig. S3. For Hengshui, the $\mathrm{PM}_{2.5}$ concentrations $\left(157.6 \mu \mathrm{g} \mathrm{m}^{-3}\right)$ carried by the air mass in Cluster 2 was the highest. The $\mathrm{Na}^{+}$concentrations in Cluster 2 were the highest, further indicating that cross-sea transports had a certain influence on the formation of $\mathrm{PM}_{2.5}$ in Hengshui. For Baoding, Cluster 3 carried $\mathrm{PM}_{2.5}$ with an average concentration of $216.7 \mu \mathrm{g} \mathrm{m}^{-3}$, moved around Baoding, indicating a great impact of local pollution sources on $\mathrm{PM}_{2.5}$ in Baoding

*Polluted trajectories: trajectories with hourly $\mathrm{PM}_{2.5}$ concentrations higher than $75 \mu \mathrm{g} \mathrm{m}^{-3}$. SD: standard deviation

**Values of chemical components are: average mass concentrations $\left(\mu \mathrm{g} \mathrm{m}^{-3}\right)$ and the fraction of chemical component $(\%)$ in parentheses for $\mathrm{PM}_{2.5}$

In summary, the $\mathrm{PM}_{2.5}$ concentrations of the three receptor cities mainly depend on the cities located in the pollution transport paths for them. The northeast transport path, especially through Liaoning province, had the substantial impact on $\mathrm{PM}_{2.5}$ in the three recipient cities. The previous studies found that the regional transports were mainly a southerly transport path for NCP (Zhu et al. 2016; Du et al. 2020; Lv et al. 2020). However, this study shows that the northeast transport path dominates the regional transport for the haze formation in the North China Plain.

\section{Identification of common source areas for pollution}

The concentrations of $\mathrm{PM}_{2.5}$ in the receptor cities were combination effects of local emissions and regional transports. Figure 3 shows the concentration weighted trajectories (CWT) for the entire and severe pollution periods and the
CWT for the light, medium and heavy pollution periods are shown in Fig. S4. Figure 3 indicates that different cities had different degrees of contributions to $\mathrm{PM}_{2.5}$ in the three cities. The regions with the CWT values higher than $250 \mu \mathrm{g} \mathrm{m}^{-3}$ (see Fig. 3) included Chaoyang and Huludao in Liaoning province, Qinhuangdao, Tangshan, Langfang and Chengde in Hebei province, and Tianjin, all of which contributed high concentrations of $\mathrm{PM}_{25}$ to Beijing. For Hengshui, the potential sources of pollution during the severe pollution period were Panjin, Anshan and Yingkou in Liaoning province. It was worth noting that Liaoning province had a large amount of $\mathrm{PM}_{2.5}$ input for Hengshui for all the pollution periods. For Baoding, Cangzhou, Langfang, Chaoyang, Jinzhou and Tianjin were potential source areas during the heavy pollution period. Note that some of the air masses from Liaoning were transported across the Bohai Sea, which is located in the east of the North China Plain. 
Fig. 2 Maps of $48 \mathrm{~h}$ polluted backward trajectories overlaid with the observations of $\mathrm{PM}_{2.5}$ concentrations $\left(\mu \mathrm{g} \cdot \mathrm{m}^{-3}\right)$ at different times (in the format of YYYYMMDD_HH). The spatial variations of $\mathrm{PM}_{2.5}$ in the three cities were consistent with those of the monitoring stations on the transport paths. The pollution incidents in Beijing were a typical full-time severe pollution event. As can be seen, the $\mathrm{PM}_{2.5}$ concentrations of the three recipient cities partly depend on the cities located on pollution transport paths for them. The northeast transport path through Liaoning province had the greatest impact on $\mathrm{PM}_{2.5}$ in the three recipient cities. The results show that the northeast transport path dominates the regional transport for the haze formation in NCP
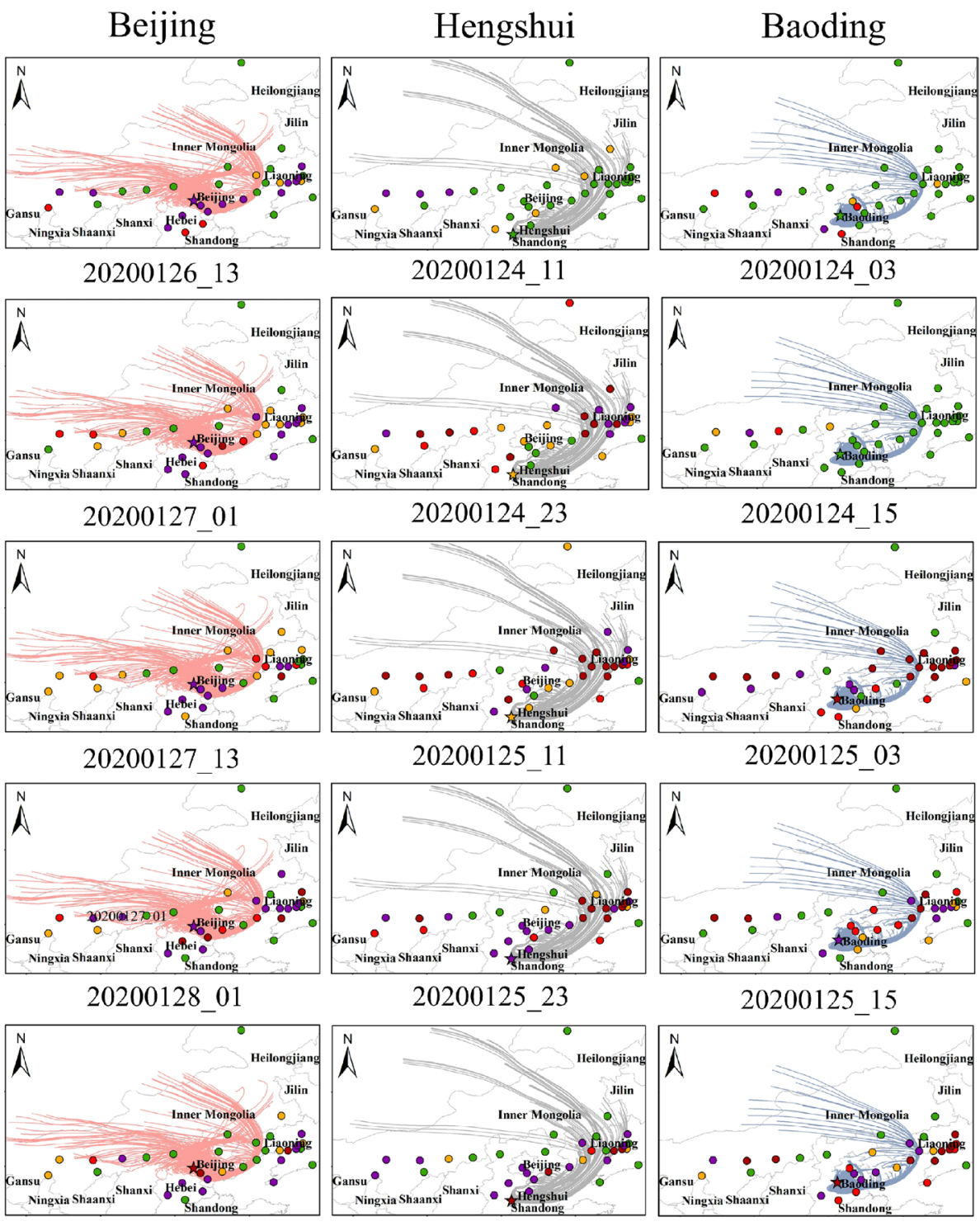

$20200128+13$
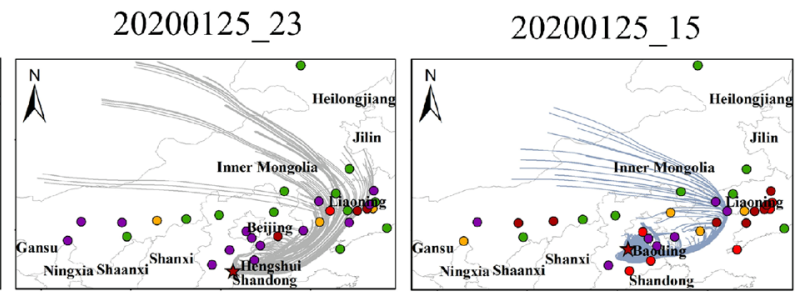

$20200126 \quad 11$

20200126_03

$151-250$

$>250$
Figure 3 shows the common source areas of $\mathrm{PM}_{2.5}$ in the three cities during the study period. Controlling the common source area is an effective choice for air pollution control (Yu et al. 2018). As can be seen, western Liaoning, northern Hebei, and southern Tianjin were the common source areas for $\mathrm{PM}_{2.5}$ pollution events in the three recipient cities. This is consistent with the fact that Hebei province is the largest industrial cluster in China (Wang et al. 2014) and Liaoning province is a region with industry as its main industry (Shi et al. 2020). Although a temporary industrial shutdown was implemented to curb the spread of COVID-19, industrial emissions have not dropped significantly due to the fact that the main industrial sectors have not yet been completely closed (Wang et al. 2020a, b).

\section{Regional transport impacts based on the WRF-CMAQ model simulations}

To determine if the northeast transport path had the substantial impact on $\mathrm{PM}_{2.5}$ in the three receptor cities during the study period, the WRF-CMAQ model was applied to simulate this regional severe haze episode in the retrospective mode. The concentration weighted trajectories (CWT) values for $\mathrm{PM}_{2.5}$ were calculated on the basis of the air mass back trajectories and their associated $\mathrm{PM}_{2.5}$ concentrations observed at the three receptor sites to locate the source areas with the largest potential contributions to high concentrations. Figure S6 shows the spatial distributions of the CWT values created by combining all results at the three 


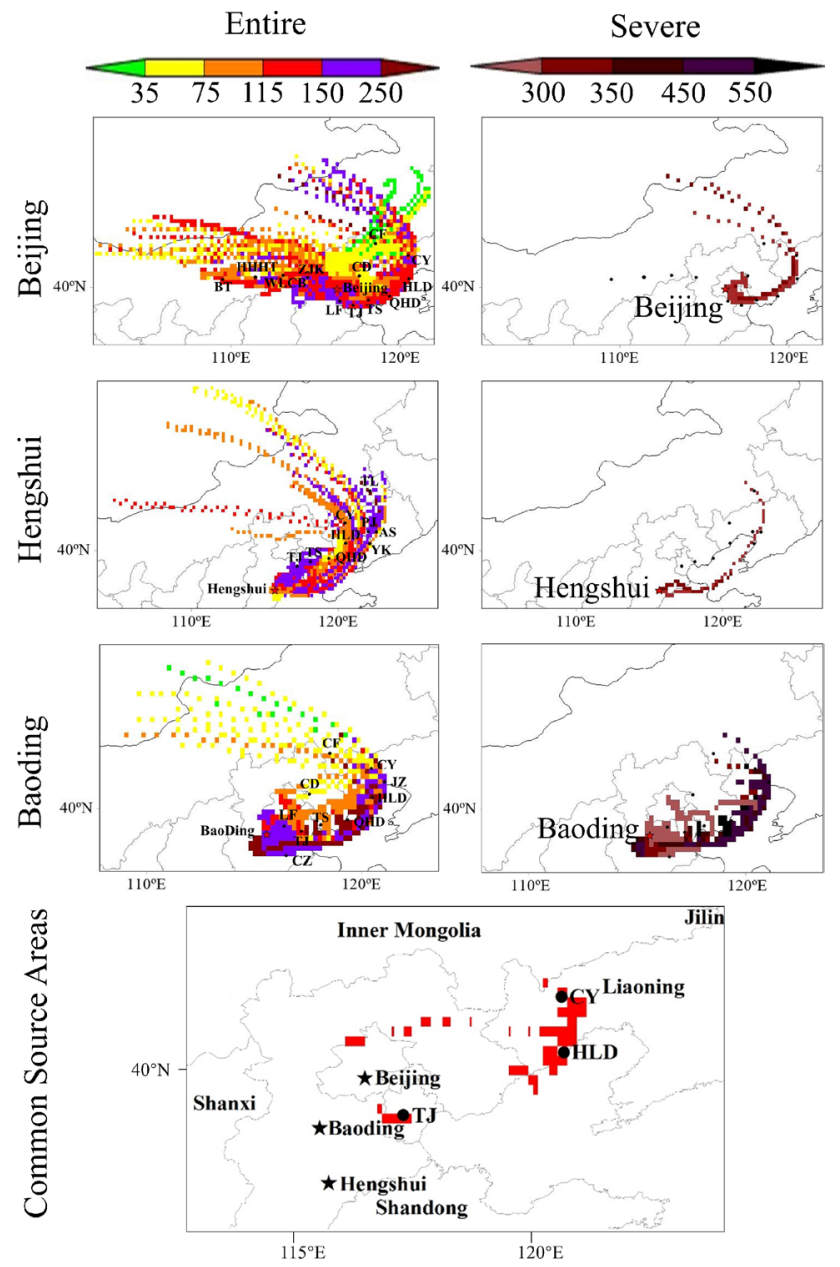

Fig. 3 Concentration weighted trajectory (CWT) maps of $\mathrm{PM}_{2.5}$ for Beijing, Hengshui, Baoding during the entire and severe haze periods $\left(\mathrm{PM}_{2.5} \geq 250 \mu \mathrm{g} \mathrm{m}^{-3}\right)$, and common source areas of $\mathrm{PM}_{2.5}$ $\left(\mathrm{PM}_{2.5} \geq 75 \mu \mathrm{g} \mathrm{m}^{-3}\right)$ during the entire study period (24th January29th January, 2020). The full names of the abbreviation of cities in the figure are as follows: AS-Anshan, BT-Baotou, CD-Chengde, CF-Chifeng, CY-Chaoyang, CZ-Cangzhou, HHHT-Hohhot, HLDHuludao, JZ-Jinzhou, LF-Langfang, PJ-Panjing, QHD-Qinhuangdao, TJ-Tianjijng, TL-Tongliao, TS-Tangshan, WLCB-Wulanchabu, YKYingkou, ZJK-Zhangjiakou. For Hengshui, the potential sources of pollution during the severe pollution period were Panjin, Anshan and Yingkou in Liaoning province. For Baoding, Cangzhou, Langfang, Chaoyang, Jinzhou and Tianjin were potential source areas during the heavy pollution period

cities during the study period. Followed Yu et al. (2016), an emission reduction scenario was created on the basis of the CWT values in Fig. S6 by removing all anthropogenic emissions for grid cells with CWT $\geq 75 \mu \mathrm{g} \mathrm{m}^{-3}$, while those will remain uncontrolled for grid cells with $\mathrm{CWT}<75 \mu \mathrm{g} \mathrm{m}^{-3}$. Figures S7 and S8 show the comparisons of the spatial distributions of anthropogenic emissions for primary $\mathrm{PM}_{2.5}, \mathrm{NH}_{3}$, $\mathrm{NO}_{\mathrm{X}}, \mathrm{SO}_{2}, \mathrm{VOC}_{\mathrm{S}}$, and $\mathrm{POC}$ between the base and reduction cases. Figure $\mathrm{S} 9$ shows the daily mean comparisons of the simulation results for the spatial distributions of $\mathrm{PM}_{2.5}$ concentrations for the base and reduction cases and their differences for each day from January 24 to 29, 2020. The maps of the $\mathrm{PM}_{2.5}$ reduction amounts between the base and reduction cases overlaid with the wind fields for different times in Fig. S10 clearly show that the prevailing northeasterly winds during study period brought air pollution continuously from the northeast areas to the North China Plain regions, causing the severe haze formation there. Comparisons of the time series of $\mathrm{PM}_{2.5}$ and its chemical components concentrations in the three receptor cities for the base and reduction cases in Fig. S11 also show that the peak values for all these pollutants in the reduction cases in the three receptor cities were effectively decreased by more than $60 \%$. As summarized in Tables S2, S3 and S4, the $\mathrm{PM}_{2.5}, \mathrm{NH}_{4}{ }^{+}, \mathrm{NO}_{3}{ }^{-}, \mathrm{OM}$, and $\mathrm{SO}_{4}{ }^{2-}$ concentrations in the reduction case decreased at most by $-106.73 \mu \mathrm{g} \mathrm{m}^{-3},-8.93 \mu \mathrm{g} \mathrm{m}^{-3},-25.96 \mu \mathrm{g} \mathrm{m}^{-3}$, $-13.75 \mu \mathrm{g} \mathrm{m}^{-3}$ and $-5.51 \mu \mathrm{g} \mathrm{m}^{-3}$ in Beijing, respectively, while they were $-144.38 \mu \mathrm{g} \mathrm{m}^{-3},-12.01 \mu \mathrm{g} \mathrm{m}^{-3}$, $-34.15 \mu \mathrm{g} \mathrm{m}^{-3},-21.77 \mu \mathrm{g} \mathrm{m}^{-3}$ and $-7.79 \mu \mathrm{g} \mathrm{m}^{-3}$ in Hengshui, respectively, and were $-148.32 \mu \mathrm{g} \mathrm{m}^{-3}$, $-12.21 \mu \mathrm{g} \mathrm{m}^{-3},-35.86 \mu \mathrm{g} \mathrm{m}^{-3},-23.68 \mu \mathrm{g} \mathrm{m}^{-3}$ and $-8.56 \mu \mathrm{g} \mathrm{m}^{-3}$ in Baoding, respectively. The mean $\mathrm{PM}_{2.5}$, $\mathrm{NH}_{4}{ }^{+}, \mathrm{NO}_{3}{ }^{-}, \mathrm{OM}$, and $\mathrm{SO}_{4}{ }^{2-}$ concentrations in the reduction case could decrease by more than $60 \%$ in the three receptor cities relative to the base case. The model sensitive simulations results highlight the fact that regional severe haze in North China Plain during the coronavirus lockdown was caused mainly by the anthropogenic emissions through the northeast transport paths.

\section{Conclusion}

This study investigated the causes of the regional severe haze over the North China Plain during the COVID-19 lockdown period on the basis of chemical observations in the three cities (Beijing, Baoding and Hengshui) and model simulations. The concentrations of $\mathrm{NO}_{3}{ }^{-}, \mathrm{SO}_{4}{ }^{2-}, \mathrm{NH}_{4}{ }^{+}$, organic matter and $\mathrm{K}^{+}$were found to be the main components of $\mathrm{PM}_{2.5}$ in Beijing and Hengshui, while they were $\mathrm{OM}$ and $\mathrm{K}^{+}, \mathrm{NO}_{3}{ }^{-}$, $\mathrm{SO}_{4}{ }^{2-}$, and $\mathrm{NH}_{4}{ }^{+}$in Baoding. The results indicate that the emissions from firework, firecrackers, residential heating, and non-stop industries under the stable meteorological conditions with low wind speed, low mixing layer height, and high relative humidity caused this severe haze pollution in North China Plain. The results of backward trajectories in the three cities indicate that most of the air masses influencing the cities came from Inner Mongolia, Liaoning, Hebei and Tianjin. For Hengshui, all cluster trajectories are cross-sea transports in the northeast direction with obvious long-distance transport characteristics by passing the western Inner Mongolia and Liaoning Province. For Baoding, the two cluster trajectories also passed through the western 
Liaoning and Inner Mongolia. It was found that the common source areas for the haze formation in the three cities were located in western Liaoning, northern Hebei, and southern Tianjin as the common source cities. The stagnant airflow and uninterrupted emissions from non-stop industries (e.g., power plants and petrochemical facilities) can still cause regional severe haze formation with high humidity to promote aerosol heterogeneous chemistry. The results of the cluster trajectories and model simulations show that different from the previous studies that mainly found a southerly transport path of air pollution for North China Plain, the northeast transport path dominates the regional transport for this haze formation. This indicates that the transport paths can be variable for a city for different haze events in regional scale. This implies that the variabilities of transport paths should be taken into account in the regulation of air pollution in the North China Plain, especially in the case of short-term severe pollutions.

Supplementary Information The online version contains supplementary material available at https://doi.org/10.1007/s10311-021-01314-8.

Acknowledgements This work was partially supported by the Department of Science and Technology of China (Nos. 2018YFC0213506, 2018YFC0213503, and 2016YFC0202702,), National Research Program for Key Issues in Air Pollution Control in China (No. DQGG0107), and National Natural Science Foundation of China (Nos. 21577126 and 41561144004). Part of this work was also supported by the "Zhejiang 1000 Talent Plan" and Research Center for Air Pollution and Health in Zhejiang University. Pengfei Li is supported by National Natural Science Foundation of China (No. 22006030), Initiation Fund for Introducing Talents of Hebei Agricultural University (412201904), and Hebei Youth Top Q15 Fund (BJ2020032).

\section{References}

An Z, Huang RJ, Zhang R et al (2019) Severe haze in northern China: a synergy of anthropogenic emissions and atmospheric processes. Proc Natl Acad Sci U S A 116:8657-8666. https:// doi.org/10.1073/pnas.1900125116

Appel KW, Bash JO, Fahey KM et al (2021) The CommunityMultiscale Air Quality (CMAQ) model versions 53 and 531: system updates and evaluation. Geosci. Model Dev 14:2867-2897. https://doi.org/10.5194/gmd-14-2867-2021

Azhagurajan A, Selvakumar N, Thanulingam TL (2011) Thermal and sensitivity analysis of nano aluminium powder for firework application. J Therm Anal Calorim 105:259-267. https://doi. org/10.1007/s10973-011-1435-7

Beyrich F (1997) Mixing height estimation from sodar data: a critical discussion. Atmos Environ 31:3941-3953. https://doi.org/10. 1016/S1352-2310(97)00231-8

Cai W, Li K, Liao H et al (2017) Weather conditions conducive to Beijing severe haze more frequent under climate change. Nature Clim Change 7:257-262. https://doi.org/10.1038/nclimate3249

Chang D, Song Y, Liu B (2009) Visibility trends in six megacities in China 1973-2007. Atmos Res 94:161-167. https://doi.org/ 10.1016/j.atmosres.2009.05.006
Chang Y, Huang RJ, Ge X et al (2020) Puzzling Haze Events in China During the Coronavirus (COVID-19) Shutdown. Geophys Res Lett. https://doi.org/10.1029/2020GL088533

Chen X, Yu S, Wang L et al (2020) Common source areas of air pollution vary with haze intensity in the Yangtze River Delta, China. Environ Chem Lett 18:957-965. https://doi.org/10.1007/ s10311-020-00976-0

Cheng Y, Engling G, He KB et al (2013) Biomass burning contribution to Beijing aerosol. Atmos Chem Phys 13:7765-7781. https://doi.org/10.5194/acp-13-7765-2013

Draxler RR, Hess GD (1998) An overview of the HYSPLIT_4 modelling system for trajectories, dispersion and deposition. Aust Meteorol Mag 47:295-308

Du H, Li J, Wang Z et al (2020) Effects of Regional Transport on Haze in the North China Plain: transport of Precursors or Secondary Inorganic Aerosols. Geophys Res Lett. https://doi.org/ 10.1029/2020GL087461

Dutheil F, Baker JS, Navel V (2020) COVID-19 as a factor influencing air pollution? Environ Pollut 263:114466. https://doi.org/ 10.1016/j.envpol.2020.114466

Ge B, Wang Z, Lin W et al (2018) Air pollution over the North China Plain and its implication of regional transport: A new sight from the observed evidences. Environ Pollut 234:29-38. https://doi. org/10.1016/j.envpol.2017.10.084

Gong S, Liu H, Zhang B et al (2021) Assessment of meteorology vs. control measures in the China fine particular matter trend from 2013 to 2019 by an environmental meteorology index. Atmos Chem Phys 21:2999-3013. https://doi.org/10.5194/ acp-21-2999-2021

He G, Pan Y, Tanaka T (2020) The short-term impacts of COVID-19 lockdown on urban air pollution in China. Nat Sustain 3:10051011. https://doi.org/10.1038/s41893-020-0581-y

Hsu YK, Holsen TM, Hopke PK (2003) Comparison of hybrid receptor models to locate PCB sources in Chicago. Atmos Environ 37:545-562. https://doi.org/10.1016/S1352-2310(02)00886-5

Jin X, Cai X, Yu M et al (2020) Diagnostic analysis of wintertime $\mathrm{PM}_{2.5}$ pollution in the North China Plain: The impacts of regional transport and atmospheric boundary layer variation. Atmos Environ 224:117346. https://doi.org/10.1016/j.atmosenv. 2020.117346

Kanawade VP, Srivastava AK, Ram K et al (2020) What caused severe air pollution episode of November 2016 in New Delhi? Atmos Environ 222:117-125. https://doi.org/10.1016/j.atmosenv.2019. 117125

Kong SF, Li L, Li XX et al (2015) The impacts of firework burning at the Chinese Spring Festival on air quality: Insights of tracers, source evolution and aging processes. Atmos Chem Phys 15:2167-2184. https://doi.org/10.5194/acp-15-2167-2015

Le T, Wang Y, Liu L et al (2020) Unexpected air pollution with marked emission reductions during the COVID-19 outbreak in China. Science. https://doi.org/10.1126/science.abb7431

Li L, Yin Y, Kong S et al (2014) Altitudinal effect to the size distribution of water soluble inorganic ions in PM at Huangshan, China. Atmos Environ 98:242-252. https://doi.org/10.1016/j.atmosenv. 2014.08.077

Liu X, Zhu B, Kang H et al (2021) Stable and transport indices applied to winter air pollution over the Yangtze River Delta. China Environ Pollut 272:115954. https://doi.org/10.1016/j. envpol.2020.115954

Lv L, Xiang Y, Zhang T et al (2020) Comprehensive study of regional haze in the North China Plain with synergistic measurement from multiple mobile vehicle-based lidars and a lidar network. Sci Total Environ 721:137773. https://doi.org/10. 1016/j.scitotenv.2020.137773

Murphy B, Nolte C, Sidi F et al (2021) The Detailed Emissions Scaling, Isolation, and Diagnostic (DESID) module in the 
Community Multiscale Air Quality (CMAQ) modeling system version 5.3.2. Geosci Model Dev 14:3407-3420. https://doi.org/ 10.5194/gmd-14-3407-2021

Nozaki KY (1973) Mixing depth model using hourly surface observations. Report 7053. USAF Environmental Technical Applications Center.

Pasquill F (1961) The estimation of the dispersion of windborne material. Meteor Mag 90:33-49

$\mathrm{Pu}$ W, Ma Z, Collett JL Jr et al (2020) Regional transport and urban emissions are important ammonia contributors in Beijing. China. Environ Pollut 265:115062. https://doi.org/10.1016/j. envpol.2020.115062

Pye HOT, Pinder RW, Piletic I et al (2013) Epoxide pathways improve model predictions of isoprene markers and reveal key role of acidity in aerosol formation. Environ Sci Technol 47:11056-11064. https://doi.org/10.1021/es402106h

Reizer M, Orza JAG (2018) Identification of $\mathrm{PM}_{10}$ air pollution origins at a rural background site. In: E3S web of conferences. doi:https://doi.org/10.1051/e3sconf/20182801031

Seidel D, Ao C, Li K (2010) Estimating climatological planetary boundary layer heights from radiosonde observations: comparison of methods and uncertainty analysis. J Geophys Res. https:// doi.org/10.1029/2009jd013680

Shi T, Zhang W, Zhou Q, Wang K (2020) Industrial structure, urban governance and haze pollution: Spatiotemporal evidence from China. Sci Total Environ. https://doi.org/10.1016/j.scitotenv. 2020.139228

Skamarock WC, Klemp JB, Dudhia J, et al (2008) A description of the advanced research WRF Version 3 (No. NCAR/TN475+STR). University Corporation for Atmospheric Research. doi: https://doi.org/10.5065/D68S4MVH

Sun Y, Chen C, Zhang Y et al (2016) Rapid formation and evolution of an extreme haze episode in Northern China during winter 2015. Sci Rep. https://doi.org/10.1038/srep27151

Sun J, Huang L, Liao H et al (2017) Impacts of regional transport on particulate matter pollution in China: a review of methods and results. Curr Pollut Rep 3:182-191. https://doi.org/10.1007/ s40726-017-0065-5

Tang M, Ji D, Gao W, Yu Z, Chen K, Cao W (2016) Characteristics of air quality in Tianjin during the spring festival period of 2015. Atmosph Ocean Sci Lett 9:15-21. https://doi.org/10.1080/ 16742834.2015.1131948

Tsai H, Chien L, Yuan C, Lin Y, Jen Y, Ie I (2012) Influences of fireworks on chemical characteristics of atmospheric fine and coarse particles during Taiwan's Lantern Festival. Atmos Environ 62:256-264. https://doi.org/10.1016/j.atmosenv.2012.08. 012

U.S. Environmental Protection Agency (US EPA) (2020) Community Multiscale Air Quality (CMAQ) model version 5.3.2, Zenodo. https://zenodo.org/record/4081737\#.X48QT9BKhaQ.

Wang YS, Yao L, Wang LL et al (2014) Mechanism for the formation of the January 2013 heavy haze pollution episode over central and eastern China. Sci China Earth Sci 17:513-528. https://doi. org/10.1007/s11430-013-4773-4

Wang P, Chen K, Zhu S et al (2020a) Severe air pollution events not avoided by reduced anthropogenic activities during COVID-19 outbreak. Resour Conserv Recycl 158:104814. https://doi.org/ 10.1016/j.resconrec.2020.104814

Wang LQ, Li MY, Yu S et al (2020b) Unexpected rise of ozone in urban and rural areas, and sulfur dioxide in rural areas during the coronavirus city lockdown in Hangzhou, China: implications for air quality. Environ Chem Lett. https://doi.org/10.1007/ s10311-020-01028-3

Wang LQ, Chen X, Zhang Y et al (2021) Switching to electric vehicles can lead to significant reductions of $\mathrm{PM}_{25}$ and $\mathrm{NO}_{2}$ across China. One Earth 4:1037-1048. https://doi.org/10.1016/j. oneear.2021.06.008

Xiao Q, Ma Z, Li S, Liu Y (2015) The impact of winter heating on air pollution in China. PLoS ONE 10:e0117311. https://doi.org/ 10.1371/journal.pone.0117311

Yan R, Yu S, Zhang Q et al (2015) A heavy haze episode in Beijing in February of 2014: characteristics, origins and implications. Atmos Pollut Res 6:867-876. https://doi.org/10.5094/APR. 2015.096

Yang Y, Liu X, Qu Y et al (2015) Formation mechanism of continuous extreme haze episodes in the megacity Beijing, China, in January 2013. Atmos Res 155:192-203. https://doi.org/10. 1016/j.atmosres.2014.11.023

Yarwood G, Jung J, Whitten G Z, et al (2015): Updates to the Carbon Bond mechanism for version 6 (CB6). In: 2010 CMAS conference, October 2010, Chapel Hill, NC, http://www.cmascenter. org/conference/2010/abstracts/ emery_updates_carbon_2010. pdf

Yu S, Mathur R, Pleim J, Wong D, Gilliam R, Alapaty K, Zhao C, Liu X (2014) Aerosol indirect efect on the grid-scale clouds in the two-way coupled WRF-CMAQ: model description, development, evaluation and regional analysis. Atmos Chem Phys 14(20):11247-11285. https://doi.org/10.5194/ acp-14-11247-2014

Yu S, Li P, Wang L et al (2018) Mitigation of severe urban haze pollution by a precision air pollution control approach. Sci Rep. https://doi.org/10.1038/s41598-018-26344-1

Zhang M, Wang X, Chen J et al (2010) Physical characterization of aerosol particles during the Chinese New Year's firework events. Atmos Environ 44:5191-5198. https://doi.org/10.1016/j. atmosenv.2010.08.048

Zhang HD, Zhang BH, Lyu MY (2017) Preliminary construction of stable weather index in Beijing and its application in environmental meteorology. Meteorology 8:100-106 (in Chinese)

Zhang Y, QiShen YY et al (2019) Mapping the agricultural land use of the North China Plain in 2002 and 2012. J Geogr Sci 29:909-921. https://doi.org/10.1007/s11442-019-1636-8

Zheng GJ, Duan FK, Su H et al (2015) Exploring the severe winter haze in Beijing: the impact of synoptic weather, regional transport and heterogeneous reactions. Atmos Chem Phys 15:29692983. https://doi.org/10.5194/acp-15-2969-2015

Zheng B, Tong D, Li M et al (2018) Trends in China's anthropogenic emissions since 2010 as the consequence of clean air actions. Atmos Chem Phys 19:14095-14111. https://doi.org/10.5194/ acp-18-14095-2018

Zhu X, Tang G, Hu B et al (2016) Regional pollution and its formation mechanism over North China plain: a case study with ceilometer observations and model simulations. J Geophys Res 121:574-588. https://doi.org/10.1002/2016JD025730

Zhu X, Tang G, Guo J, Hu B, Song T, Wang L et al (2018) Mixing layer height on the North China Plain and meteorological evidence of serious air pollution in southern Hebei. Atmos Chem Phys 18:4897-4910. https://doi.org/10.5194/acp-18-4897-2018

Zhu Y, Hu Q, Gao M et al (2021) Quantifying contributions of local emissions and regional transport to NOX in Beijing using TROPOMI constrained WRF-Chem simulation. Remote Sens 13:1798. https://doi.org/10.3390/rs13091798

Publisher's Note Springer Nature remains neutral with regard to jurisdictional claims in published maps and institutional affiliations. 